\title{
Hot Water and Chemical Dips for Nematode Control in Tubers of Dioscorea Rotundata Poir ${ }^{1,2}$
}

\author{
Nelia Acosta and Alejandro Ayala ${ }^{3}$
}

\begin{abstract}
Immersion of Guinea yam tubers (Dioscorea rotundata Pior) in hot water at $35^{\circ}, 46^{\circ}, 48^{\circ}, 50^{\circ}, 52^{\circ}$, and $54^{\circ} \mathrm{C}$ effectively controlled nematodes causing dry rot, regardless of the period of exposure. The tuber tissue was severely damaged by immersion in water at $65^{\circ} \mathrm{C}$. Immersion in 300,600 , and $1200 \mathrm{p} / \mathrm{m}$ of Nemagon effectively controlled the nematodes present to a depth of $6 \mathrm{~mm}$ in the tuber tissue. Treatment with Dasanit and Nemafos at concentrations of $1250 \mathrm{p} / \mathrm{m}$ for 15 to $30 \mathrm{~min}$, respectively, was also effective for nematode control in yams. The results were rather erratic at depths greater than $6 \mathrm{~mm}$. Germination was not affected by hot water or chemical dips.
\end{abstract}

\section{INTRODUCTION}

The local demand for the Guinea yam (Dioscorea rotundata Poir) is increasing in Puerto Rico, but production and quality of the crop is decreasing. This probably is due in part to a number of diseases caused by agents such as fungi, viruses, and nematodes. Among the latter, Pratylenchus coffeae (Zimmermann) Filip. Schuur-Stekh., damages the yam tuber $(1,2,3)$, causing the condition known as dry rot which has been previously reported to be caused by Scutellonema bradys (Steiner \& Lehew) Andrassy (11). This disease is expressed as a severe necrosis and cracking of the tuber cortex, which reduces quality and hence value for both local consumption and exportation.

The nematodes easily spread to clean soils through the indiscriminate use of infected tubers for propagation. They are now widely distributed among the commercial plantings in the Island as evidenced by a survey conducted in the areas of San Lorenzo, Las Piedras, Yabucoa, Corozal, Utuado, Isabela, and Aguada.

Guinea yam production in the Island could be increased by controlling the nematodes attacking the yam tubers. Among the different nematode

${ }^{1}$ Manuscript submitted to Editorial Board September 18, 1974.

${ }^{2}$ Portion of a thesis submitted to the Graduate School at the University of Puerto Rico, Mayagüez Campus, for the M.S. degree in Agriculture.

${ }^{3}$ Assistant Nematologist and Nematologist, Department of Entomology, Agricultural Experiment Station, Mayagüez Campus, University of Puerto Rico, Rio Piedras, P. R. 
control methods discussed in the literature, hot water baths $(4,5,8)$ and chemical dips $(4,9)$ of the tubers have been effectively employed for nematode control. Based on these reports, both methods were evaluated in the present report of several experiments for the control of the lesion nematode and others inside tubers.

\section{MATERIALS AND METHODS}

Six laboratory experiments using hot water or chemical immersions were performed for the control of phytoparasitic nematodes attacking Guinea yam tuber. Cross sections of nematode-infected apical portions of the tuber, usually preferred for propagation in commercial plantings, were used. The sections were immersed in water at different temperatures in a constant temperature tank or in different concentrations of Nemagon ${ }^{4}$ (DBCP), Dasanit (Fensulfothion), and Nemafos (Thionazin) for periods of $7,15,30,45$, or $60 \mathrm{~min}$. Yam sections immersed in water at $25^{\circ} \mathrm{C}$ for 15,30 , and $60 \mathrm{~min}$ were used as controls. Four samples consisting of $15 \mathrm{~g}$ of tissue $3 \mathrm{~mm}$ thick ( 0 to 3,3 to 6,6 to 9 , and 9 to 12 $\mathrm{mm}$ deep) were taken from each tuber section immersed in hot water or in the nematicide solution. The nematodes present were extracted using the Baermann funnel method (7). Population densities were recorded after $24 \mathrm{hr}$.

\section{NEMATODE CONTROL BY HOT WATER DIPS}

In the first test the tubers were immersed in hot water at $25^{\circ} \mathrm{C}$ (control), and at $35^{\circ}, 50^{\circ}$, and $65^{\circ} \mathrm{C}$ for periods of 15,30 , and $60 \mathrm{~min}$. In the second experiment the tubers were immersed in hot water at $25^{\circ} \mathrm{C}$ (control), and at $46^{\circ}, 48^{\circ}, 50^{\circ}, 52^{\circ}$, and $54^{\circ} \mathrm{C}$ for the same exposure periods used in the first test. No germination tests were performed because the tubers were in their quiescent period. In a third test tubers were immersed in hot water at $46^{\circ} \mathrm{C}$ for 45 and $60 \mathrm{~min}, 48^{\circ} \mathrm{C}$ for 30 and $45 \mathrm{~min}, 50^{\circ} \mathrm{C}$ for 15 and $30 \mathrm{~min}$, and $52^{\circ} \mathrm{C}$ for 7 and $15 \mathrm{~min}$. After treatment, tubers were planted in steam sterilized soil. Plants were allowed to germinate and data on weight of tuber cortex, fresh weight of roots, and dry weight of stem were recorded at harvest 2 months later. Nematode population densities in $150 \mathrm{~cm}^{3}$ of soil and in $3 \mathrm{~g}$ of chopped roots were determined. A complete randomized block design was used in all the tests and each treatment was replicated four times.

"Trade names are used in this publication solely for the purpose of providing specific information. Mention of a trade name does not constitute a guarantee or warranty of equipment or material by the Agricultural Experiment Station of the University of Puerto Rico or an endorsement over other equipment or materials not mentioned. 
NEMATODE CONTROL BY CHEMICAL DIPS

Solutions containing 300,600 , and $1,200 \mathrm{p} / \mathrm{m}$ of Nemagon were used to immerse tuber sections for 15,30 , and $60 \mathrm{~min}$. Germination tests were not performed. In a second experiment solutions of 1,250 and $2,500 \mathrm{p} / \mathrm{m}$ of Dasanit were employed to treat tuber sections for 15 and $30 \mathrm{~min}$. In a third test tuber sections were immersed in solutions of $625,1,250$, and $2,500 \mathrm{p} / \mathrm{m}$ of Dasanit, Nemagon, and Nemafos for 30 and $60 \mathrm{~min}$. The procedures used to submerge the tuber sections, to take samples, and to determine the nematode population density were similar to those used in the hot water tests. A complete randomized block design was used with four replicates per treatment.

TABle 1.-Mean nematode population density in $15 \mathrm{~g}$ of Guinea yam tuber (Dioscorea rotundata Poir) tissue at different depth of tuber after being immersed in hot water at four temperatures for different periods of time

\begin{tabular}{ccrrr}
\hline \multirow{2}{*}{ Temperature } & $\begin{array}{c}\text { Exposure } \\
\text { time }\end{array}$ & \multicolumn{3}{c}{$\begin{array}{c}\text { Nematode population at } \\
\text { different depths (mm) }\end{array}$} \\
\cline { 3 - 4 } & Min & 0 to 3 & 3 to 6 & 6 to 9 \\
\hline${ }^{\circ} \mathrm{C}$ & 15 & $44,545 \mathrm{~b}^{1}$ & $28,188 \mathrm{~b}$ & $2,214 \mathrm{a}$ \\
$25^{\circ}$ & 30 & $1,085 \mathrm{a}$ & $1,076 \mathrm{a}$ & $185 \mathrm{a}$ \\
& 60 & $1,166 \mathrm{a}$ & $1,03 \mathrm{a}$ & $545 \mathrm{a}$ \\
$35^{\circ}$ & 15 & $923 \mathrm{a}$ & $1,733 \mathrm{a}$ & $364 \mathrm{a}$ \\
& 30 & $3,645 \mathrm{a}$ & $3,888 \mathrm{a}$ & $2,043 \mathrm{a}$ \\
$50^{\circ}$ & 60 & $2,948 \mathrm{a}$ & $1,746 \mathrm{a}$ & $113 \mathrm{a}$ \\
& 15 & $212 \mathrm{a}$ & $32 \mathrm{a}$ & $45 \mathrm{a}$ \\
$65^{\circ}$ & 30 & $293 \mathrm{a}$ & $288 \mathrm{a}$ & $36 \mathrm{a}$ \\
& 60 & $140 \mathrm{a}$ & $68 \mathrm{a}$ & $0 \mathrm{a}$ \\
& 15 & $0 \mathrm{a}$ & $0 \mathrm{a}$ & $0 \mathrm{a}$ \\
& 30 & $0 \mathrm{a}$ & $0 \mathrm{a}$ & $0 \mathrm{a}$ \\
\hline
\end{tabular}

${ }^{1}$ Means in the same column followed by the same letter are not significantly different at the .05 level by Duncan's New Multiple Range test.

\section{RESULTS}

\section{NEMATODE CONTROL BY HOT WATER DIPS}

Effective nematode control was obtained immersing Guinea yam tuber sections in hot water at $35^{\circ}, 50^{\circ}$, and $65^{\circ} \mathrm{C}$ for 15,30 , or 60 min (table 1 ). The best control of nematodes in the outer layer was obtained at temperatures of $50^{\circ}$ or $65^{\circ} \mathrm{C}$; but the tuber tissue was destroyed at the higher temperature. The results were erratic beyond a $6 \mathrm{~mm}$ depth of tuber tissue. No nematodes were recovered at any depth at $65^{\circ} \mathrm{C}$ (table 1). 
All the treatments effectively controlled nematodes when compared with the control at any exposure time used (table 2) in the second test.

In the third test greatest dry stem weight was obtained when yam tubers were immersed in water at $52^{\circ} \mathrm{C}$ for $7 \mathrm{~min}$ (table 3 ). The fresh weight of roots and the weight of the cortex increased 90 and $81 \%$ respectively, over the control. Nematodes were not recovered from the soil around the treated tubers.

TABLE 2.-Mean nematode population density in $15 \mathrm{~g}$ of Guinea yam (Dioscorea rotundata Poir) tuber tissue after being immersed in hot water at six temperatures for different periods of time

\begin{tabular}{ccc}
\hline Temperature & Exposure time & $\begin{array}{c}\text { Nematode population } \\
\text { (15 g of tuber tissue) }\end{array}$ \\
\hline${ }^{\circ} \mathrm{C}$ & Min & $828 \mathrm{~b}^{1}$ \\
$25^{\circ}$ & 15 & $840 \mathrm{~b}$ \\
& 30 & $865 \mathrm{~b}$ \\
& 60 & $150 \mathrm{a}$ \\
$46^{\circ}$ & 15 & $15 \mathrm{a}$ \\
& 30 & $0 \mathrm{a}$ \\
& 60 & $12 \mathrm{a}$ \\
$48^{\circ}$ & 15 & $12 \mathrm{a}$ \\
& 30 & $0 \mathrm{a}$ \\
$50^{\circ}$ & 60 & $18 \mathrm{a}$ \\
& 15 & $18 \mathrm{a}$ \\
& 30 & $9 \mathrm{a}$ \\
$52^{\circ}$ & 60 & $3 \mathrm{a}$ \\
& 15 & $0 \mathrm{a}$ \\
& 30 & $0 \mathrm{a}$ \\
$54^{\circ}$ & 60 & $17 \mathrm{a}$ \\
& 15 & $0 \mathrm{a}$ \\
\end{tabular}

${ }^{1}$ Means in the same column followed by the same letter are not significantly different at the .05 level by Duncan's New Multiple Range test.

NEMATODE CONTROL BY CHEMICAL DIPS

Nematode populations in the controls (tubers immersed in water for 30 or $60 \mathrm{~min}$ ) were higher than those recovered from the tubers treated with Nemagon at concentrations of 300,600 , or $1,200 \mathrm{p} / \mathrm{m}$. These concentrations effectively controlled the nematodes inside the tuber tissue. However, nematode kill in tissue deeper than $6 \mathrm{~mm}$ was rather erratic. The best results were obtained with concentrations of Nemagon at 600 $\mathrm{p} / \mathrm{m}$ at depths of $3 \mathrm{~mm}$ compared with the controls. Good control was attained when tubers were immersed in Nemagon solution at 300 or 1,200 $\mathrm{p} / \mathrm{m}$ (table 4). 
Table 5 lists the mean fresh weight of the cortex and roots and the dry weight of stems of yam plants grown from tubers treated with different concentrations of Dasanit for different exposure periods. None of the rates gave significant growth differences over the control. However, there was a tendency toward higher stem dry weight with concentrations of $1,250 \mathrm{p} / \mathrm{m}$ for $15 \mathrm{~min}$. Concentrations of $2,500 \mathrm{p} / \mathrm{m}$ curtailed plant growth.

Table 6 shows the dry weight of stems and fresh weight of roots of yam plants from tubers treated with Dasanit, Nemagon, and Nemafos at different exposure times. There were no significant differences among treatments in stem dry weights or root fresh weights.

TABLE 3.- Mean weight of tuber cortex, fresh roots and dry stem of plants of Guinea yam (Dioscorea rotundata Poir) grown from tuber sections treated with hot water at different temperatures for different periods of time

\begin{tabular}{ccccc}
\hline Temperature & $\begin{array}{c}\text { Exposure } \\
\text { time }\end{array}$ & $\begin{array}{c}\text { Fresh } \\
\text { cortex }\end{array}$ & $\begin{array}{c}\text { Fresh } \\
\text { roots }\end{array}$ & $\begin{array}{c}\text { Dry } \\
\text { stem }\end{array}$ \\
\cline { 3 - 5 } & Min & & $g$ \\
$25^{\circ}$ & 30 & $1.38 \mathrm{ab}$ & $10.44 \mathrm{ab}$ & $5.88 \mathrm{a}$ \\
$46^{\circ}$ & 45 & $.31 \mathrm{~b}$ & $3.40 \mathrm{~b}$ & $1.68 \mathrm{a}$ \\
& 60 & $1.90 \mathrm{ab}$ & $12.79 \mathrm{ab}$ & $4.58 \mathrm{a}$ \\
$48^{\circ}$ & 30 & $.97 \mathrm{ab}$ & $6.57 \mathrm{ab}$ & $3.38 \mathrm{a}$ \\
& 45 & $.60 \mathrm{~b}$ & $8.97 \mathrm{ab}$ & $3.94 \mathrm{a}$ \\
$50^{\circ}$ & 15 & $1.50 \mathrm{ab}$ & $9.53 \mathrm{ab}$ & $3.67 \mathrm{a}$ \\
& 30 & $1.23 \mathrm{ab}$ & $4.10 \mathrm{~b}$ & $1.09 \mathrm{a}$ \\
$52^{\circ}$ & 7 & $2.51 \mathrm{a}$ & $19.94 \mathrm{a}$ & $12.60 \mathrm{~b}$ \\
& 15 & $1.94 \mathrm{ab}$ & $12.98 \mathrm{ab}$ & $5.36 \mathrm{a}$ \\
\hline
\end{tabular}

${ }^{1}$ Means in the same column followed by the same letter are not significantly different at the .05 level by Duncan's New Multiple Range test.

\section{DISCUSSION}

Results obtained from the first two experiments using hot water dips at $35^{\circ}, 50^{\circ}$, and $65^{\circ} \mathrm{C}$, and $46^{\circ}, 40^{\circ}, 50^{\circ}, 52^{\circ}$, and $54^{\circ} \mathrm{C}$ for the control of phytoparasitic nematodes inside the yam tuber compare with those obtained by Ayala and Acosta (4). They reported good nematode control using water at $45^{\circ} \mathrm{C}$ for 15 to $60 \mathrm{~min}$. Bruhn and Wolfgang (5) found that dipping the seed in water at $45^{\circ} \mathrm{C}$ for $30 \mathrm{~min}$ also was effective.

Results from the first test were rather erratic when compared to those from the second experiment. That may have been due to the fact that the tuber sections used in the first trial were heavily infected and extremely damaged, with thick corky tissue which probably inhibited penetration of heat to deeper levels. 
Nemagon solutions effectively controlled nematodes in yam tubers. These results confirm those of Ayala and Acosta (4) who controlled nematodes in yam tubers by dipping the seed piece in $625 \mathrm{p} / \mathrm{m}$ of Nemagon for $60 \mathrm{~min}$. The nematode kill in that test was also erratic, which may have been caused by the method used and the thick corky tissue covering the damaged tubers. This corky tissue probably reduced the penetration of heat and chemicals, thus allowing the survival of nematodes present in tissue deeper than $6 \mathrm{~mm}$ in the tuber tissue.

TABle 4.-Mean nematode population density in $15 \mathrm{~g}$ of Guinea yam tuber (Dioscorea rotundata Poir) tissue at different depths of tuber after being immersed in Nemagon $(D B C P)$ solutions for three periods of time

\begin{tabular}{rrrrr}
\hline \multirow{2}{*}{ Nemagon } & $\begin{array}{c}\text { Exposure } \\
\text { time }\end{array}$ & \multicolumn{3}{c}{$\begin{array}{c}\text { Nematode population at } \\
\text { different depths (mm) }\end{array}$} \\
\cline { 3 - 5 }$P / m$ & Min & 0 to 3 & 3 to 6 & 6 to 9 \\
0 & 15 & $44,545 \mathrm{~b}^{1}$ & $2,888 \mathrm{~b}$ & $2,21 \mathrm{ab})$ \\
& 30 & $1,085 \mathrm{a}$ & $1,076 \mathrm{a}$ & $185 \mathrm{a}$ \\
300 & 60 & $1,166 \mathrm{a}$ & $1,031 \mathrm{a}$ & $545 \mathrm{a}$ \\
& 15 & $1,256 \mathrm{a}$ & $1,620 \mathrm{a}$ & $1,327 \mathrm{ab}$ \\
600 & 30 & $2,331 \mathrm{a}$ & $1,809 \mathrm{a}$ & $1,697 \mathrm{ab}$ \\
& 60 & $688 \mathrm{a}$ & $1,486 \mathrm{a}$ & $826 \mathrm{ab}$ \\
1200 & 15 & $180 \mathrm{a}$ & $571 \mathrm{a}$ & $288 \mathrm{a}$ \\
& 30 & $529 \mathrm{a}$ & $517 \mathrm{a}$ & $738 \mathrm{ab}$ \\
& 60 & $6,114 \mathrm{a}$ & $405 \mathrm{a}$ & $328 \mathrm{a}$ \\
& 15 & $184 \mathrm{a}$ & $6,665 \mathrm{a}$ & $33,099 \mathrm{~b}$ \\
& 30 & $517 \mathrm{a}$ & $40 \mathrm{a}$ & $40 \mathrm{a}$ \\
& 60 & $540 \mathrm{a}$ & $103 \mathrm{a}$ \\
\hline
\end{tabular}

${ }^{1}$ Means in the same column followed by the same letter are not significantly different at the .05 level by Duncan's New Multiple Range test.

TABLE 5.-Mean fresh weights of the tuber cortex and plant roots and the dry weights of the stem of plants of Guinea yam (Dioscerea rotundata) from tuber sections treated with Dasanit for different periods of time

\begin{tabular}{rcccc}
\hline Dasanit & $\begin{array}{c}\text { Exposure } \\
\text { time }\end{array}$ & $\begin{array}{c}\text { Fresh } \\
\text { cortex }\end{array}$ & $\begin{array}{c}\text { Fresh } \\
\text { roots }\end{array}$ & $\begin{array}{c}\text { Dry } \\
\text { stem }\end{array}$ \\
\cline { 3 - 5 } & Min & & $g$ & \\
0 & 30 & $1.38 \mathrm{a}^{1}$ & $10.44 \mathrm{ab}$ & $5.88 \mathrm{ab}$ \\
1250 & 15 & $1.43 \mathrm{a}$ & $19.48 \mathrm{~b}$ & $8.56 \mathrm{~b}$ \\
2500 & 1,5 & $.99 \mathrm{a}$ & $3.39 \mathrm{a}$ & $1.04 \mathrm{a}$ \\
1250 & 30 & $1.60 \mathrm{a}$ & $10.31 \mathrm{ab}$ & $6.00 \mathrm{ab}$ \\
2500 & 30 & $.85 \mathrm{a}$ & $3.46 \mathrm{a}$ & $3.04 \mathrm{ab}$ \\
\hline
\end{tabular}

${ }^{2}$ Means in the same column followed by the same letter are not significantly different at the .05 level by Duncan's New Multiple Range test. 
TABLE 6.-Mean weights of dry stem and fresh roots of plants of Guinea yam (Dioscorea rotundata) grown from tuber sections treated with different nematicides for different periods of time

\begin{tabular}{|c|c|c|c|}
\hline \multirow[b]{2}{*}{ Nematicide } & \multirow{2}{*}{$\begin{array}{l}\text { Exposure } \\
\text { time }\end{array}$} & \multicolumn{2}{|c|}{ Average weight } \\
\hline & & $\begin{array}{l}\text { Dry } \\
\text { stem }\end{array}$ & $\begin{array}{l}\text { Fresh } \\
\text { roots }\end{array}$ \\
\hline $\mathrm{P} / \mathrm{m}$ & Min & \multicolumn{2}{|c|}{$g$} \\
\hline 0 & 60 & $13.53 \mathrm{a}^{1}$ & $44.08 \mathrm{ab}$ \\
\hline \multicolumn{4}{|l|}{ Dasanit } \\
\hline \multirow[t]{2}{*}{625} & 30 & $13.55 \mathrm{a}$ & $48.25 \mathrm{ab}$ \\
\hline & 60 & $8.50 \mathrm{a}$ & $8.88 \mathrm{~b}$ \\
\hline \multirow[t]{2}{*}{1250} & 30 & $17.74 \mathrm{a}$ & $31.45 \mathrm{ab}$ \\
\hline & 60 & $14.81 \mathrm{a}$ & $22.50 \mathrm{ab}$ \\
\hline \multirow[t]{2}{*}{2500} & 30 & $20.15 a$ & $36.83 \mathrm{ab}$ \\
\hline & 60 & $16.60 \mathrm{a}$ & $42.98 \mathrm{ab}$ \\
\hline \multicolumn{4}{|l|}{ Nemagon } \\
\hline \multirow[t]{2}{*}{625} & 30 & $15.00 \mathrm{a}$ & $44.60 \mathrm{ab}$ \\
\hline & 60 & $9.60 \mathrm{a}$ & $13.80 \mathrm{ab}$ \\
\hline \multirow[t]{2}{*}{1250} & 30 & $13.58 \mathrm{a}$ & $34.25 \mathrm{ab}$ \\
\hline & 60 & $12.50 \mathrm{a}$ & $23.65 \mathrm{ab}$ \\
\hline \multirow[t]{2}{*}{2500} & 30 & $15.10 \mathrm{a}$ & $39.75 \mathrm{ab}$ \\
\hline & 60 & $14.05 \mathrm{a}$ & $29.38 a b$ \\
\hline \multicolumn{4}{|l|}{ Nemafos } \\
\hline \multirow[t]{2}{*}{625} & 30 & $12.35 \mathrm{a}$ & $31.75 \mathrm{ab}$ \\
\hline & 60 & $6.73 \mathrm{a}$ & $29.63 \mathrm{ab}$ \\
\hline \multirow[t]{2}{*}{1250} & 30 & $12.28 \mathrm{a}$ & 49.38 a \\
\hline & 60 & $11.09 \mathrm{a}$ & $28.58 \mathrm{ab}$ \\
\hline \multirow[t]{2}{*}{2500} & 30 & $14.10 \mathrm{a}$ & $33.65 \mathrm{ab}$ \\
\hline & 60 & $8.40 \mathrm{a}$ & $24.65 \mathrm{ab}$ \\
\hline
\end{tabular}

${ }^{1}$ Means in the same column followed by the same letter are not significantly different at the .05 level by Duncan's New Multiple Range test.

Other chemical treatments, such as $1,250 \mathrm{p} / \mathrm{m}$ of Dasanit for $15 \mathrm{~min}$ and $1,250 \mathrm{p} / \mathrm{m}$ of Nemafos for $30 \mathrm{~min}$, were also effective for the control of nematodes in the yam tuber tissue.

The results obtained with different nematicides indicate that immersion in $1,250 \mathrm{p} / \mathrm{m}$ for 15 to $30 \mathrm{~min}$ is enough to control nematodes inside the tuber tissue without affecting germination.

\section{CONCLUSIONS}

Based on the results obtained in these tests, it is concluded that the propagating material of the Guinea yam cultivar should be treated either with hot water or chemical dips before planting. The use of extremely damaged tubers should be avoided because the treatment would not be effective due mainly to the protective barrier provided by corky tissue. Hot water at $46^{\circ}$ to $52^{\circ} \mathrm{C}$ should be preferred for the treatment of yam 
tubers for 15 to $30 \mathrm{~min}$ to control the nematodes inside yam tissue without affecting germination.

\section{RESUMEN}

Inmersiones de tubérculos de ñame de Guinea, Dioscorea rotundata Poir, en agua caliente a $35,46,48,50,52$ y $54^{\circ} \mathrm{C}$. por siete hasta 60 minutos resultaron eficaces para el. control de los nematodos fitoparasíticos del tejido. El agua a $65^{\circ} \mathrm{C}$. fue detrimental al tejido. Los nematodos presentes en los tubérculos de ñame se controlaron hasta una profundidad de $6 \mathrm{~mm}$., al sumergir la semilla (pedazos del tubérculo) en soluciones de 300, 600 y 1200 p.p.m. de Nemagon. Inmersiones en soluciones conteniendo 1,250 p.p.m. de Dasanit y Nemafos por 15 a 30 min. y 30 min., respectivamente también los controlaron eficazmente. Los resultados fueron erráticos a profundidades mayores de $6 \mathrm{~mm}$. La germinación de los tubérculos no fue afectada por las inmersiones en agua caliente o en soluciones nematicidas.

\section{LITERATURE CITED}

1. Acosta, N., Depth of penetration of phytoparasitic nematodes in yam tubers, Nematropica 4(1): 7-11, 1974.

2. Acosta, N., and Ayala, A., Pathogenicity of Pratylenchus coffeae, Scutellonema bradys, Meloidogyne incognita and Rotylenchulus reniformis in Dioscorea rotundata, J. Nematol. 7(1): 1-6, 1975.

3. Ayala, A., Nematode problems in Puerto Rican agriculture, Proc. Symp. Trop. Nematology, 138-9, 1969.

4. - , and Acosta, N., Observations on yam (Dioscorea alata) nematodes, Nematropica 1: 39-40 (Abstr.) 1971.

5. Bruhn, C., and Wolfgang, K., Control of root-knot nematodes in Discorea tubers, Phytopathology 53: 24 (Abstr.) 1962.

6. Coursey, D. C., Yams, Longmans Green Press, London, 230 pp. 1967.

7. Goodey, J. B., Laboratory methods of work with plant and soil nematodes, Min. Agr. Fish, and Food, Tech. Bull. 2, London, 72, pp., 1963.

8. Hawley, W. O., Hot water treatments for the control of root-knot nematodes on Dioscorea floribunda, Plant Dis. Rep. 40: 1045-6, 1956.

9. Mullin, R. S., Control of cracking in sweet potato by fumigation, Phytopathology 42: 15 (Abstr.) 1952.

10. Waitt, A. W., Yams, Dioscorea species, Field Crops (Abstr.) 16: 145-57, 1963.

11. West, J., Dry rot of yams, Imp. Inst. London, Bull. 32: 448-50, 1934. 